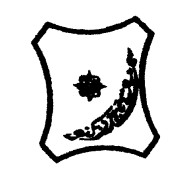

Bayero Journal of Pure and Applied Sciences, 12(1):176 - 180

Received: March, 2018

Accepted: December, 2018

ISSN $2006-6996$

\title{
EFFECT OF PAINT INDUSTRY EFFLUENT ON THE GROWTH PERFORMANCES AND BIOMASS PRODUCTION OF Telfairia occidentalis Hook (F.)
}

\begin{tabular}{|c|c|}
\hline & $\begin{array}{l}\qquad \mathbf{1}^{*} \text { Sam, S. M, and }{ }^{2} \text { Etim, A. U } \\
{ }^{1} \text { Department of Biological Sciences, Akwa Ibom State University, Ikot Akpaden } \\
\text { 2Department of Plant Science and Biotechnology, University of Port Harcourt } \\
\text { *Corresponding author Email: sundaysam@aksu.edu.ng, eosamviek@yahoo.com }\end{array}$ \\
\hline & $\begin{array}{l}\text { ABSTRACT } \\
\text { The effect of paint industry effluent on the growth performances and biomass production } \\
\text { of Telfairia occidentalis was investigated. The physicochemical properties of the effluent } \\
\text { and experimental soil were analyzed. The effluent had a high BOD of } 35 \mathrm{mg} / \mathrm{l} \text { and pH of } \\
6.99 \text {. The growth parameters and biomass were significantly (p<0.005) reduced with } \\
\text { increase in the level of the effluent as compared to the control. Higher concentrations of } \\
\text { the paint effluent at } 90 \mathrm{~m} / \text { were inhibitory to the germination and growth performances of } \\
\text { Telfairia occidentalis. This study suggests that higher concentrations of paint industry } \\
\text { effluent could be detrimental to the growth and biomass of Telfairia occidentalis. } \\
\text { KEYWORD: Biomass, Effluent, Growth, Paint, Telfairia occidentalis }\end{array}$ \\
\hline
\end{tabular}

\section{INTRODUCTION}

Telfairia occidentalis is a perennial, dioecious herb climbing by coiled, often branched tendrils to a height of more than $20 \mathrm{~m}$; root system ramifying in the top surface of the soil; stem angular, glabrous, becoming fibrous when old. Leaves arranged spirally, pedately compound with 3-5 leaflets; stipules absent; petiole (2-)4$11(-15) \mathrm{cm}$ long; leaflets with petiolules $0.5-3.5$ $\mathrm{cm}$ long, central one largest, up to $15(-19) \mathrm{cm}$ $\times 10(-12) \mathrm{cm}$, lateral ones asymmetrical, usually dentate in the upper two-thirds, sometimes scabrid underneath, 3-veined from near the base. Male inflorescence an auxillary raceme up to $3(-5.5) \mathrm{cm}$ long, on a peduncle up to $25 \mathrm{~cm}$ long, with at base of peduncle one longpedicellate flower flowering long before the others; female flowers solitary in leaf axils (Renner et. al., 2007). Flowers 5-merous, cream coloured, pedicel up to $4 \mathrm{~cm}$ long, receptacle campanulate, sepals triangular, up to $5 \mathrm{~mm}$ long, petals free, oblong, fringed; male flowers with 3 stamens, two 4-locular and one 2-locular, with large reddish connective; female flowers similar to male flowers but with inferior, cylindrical, 3-celled ovary and 3 large, heartshaped stigmas.Fruit a drooping, ellipsoid berry 40-95 cm × 20-50 cm, weighing up to $6 \mathrm{~kg}$, with 10 prominent ribs, pale green and covered with white bloom wax, fruit pulp yellow, manyseeded. Seeds compressed ovoid, up to $4.5 \mathrm{~cm}$ long, black or brown-red. Seedling with hypogeal germination, developing first a taproot and then numerous, spreading axillary roots; epicotyl 5$12 \mathrm{~cm}$ long; cotyledons planoconvex, fleshy (Renner et. al., 2007).

The main use of Telfairia occidentalis is as a leaf and seed vegetable. The tender shoots, succulent leaves and immature seeds are cooked and consumed as a vegetable. The leaves are used alone or together with okra (Abelmoschus caillei (A.Chev.) Stevels and Abelmoschus esculentus (L.) Moench), dika nut (Irvingia gabonensis (Aubry-Lecomte ex O'Rorke) Baill.), or egusi seeds (Citrullus lanatus (Thunb.) Matsum. \& Nakai and other species). They can also be mixed with eru (Gnetum africanum Welw.) and Pterocarpus soyauxii Taub. They are often cooked with fish, meat and tapioca. Immature seeds are cooked or roasted. Seeds can also be fermented for several days and eaten as slurry. The fruit pulp with young seeds is occasionally made into marmalade. The roots are used as rodenticide and ordeal poison (Gill, 1992). The diet preparation of the air-dried leaves of the plant significantly increased red blood cell count, packed cell volume and haemoglobin concentration in rats (Alada, 2000). The roots are known locally as human potent human, fish and rodents poison. The plant also contains considerable amount of anti nutrients, such as phytic acid, tannin and saponin which could also have some health benefits. They have been flouted whole fruit of Telfiaria occidentalis effectively used in lowering blood cholesterol and preventing blood clotting (Weiner, 1992). 
BAJOPAS Volume 12 Number 1, June, 2019

Wastewater effluent is the final product of all earlier treatment processes, and it can be discharged to a stream, river, bay, lagoon or wetland. Sometimes effluent is used to irrigate a golf course, green belt or park, or to recharge groundwater. In recent years, increasing awareness of water pollution and its far reaching effects has prompted concerted efforts towards pollution abatement (Donmez et al., 1999; Igbinosa and Okoh, 2009).The rate at which effluents is discharged into the environment and water bodies, has been on the increase due to rapid growth of cities in the world. Generally, water bodies are major sites of heavy metal deposits due to the fact that streams and rivers flow through agricultural areas where pesticides and fungicides may have been used, through industrial districts where there may have been many metal waste deposits or direct discharge of effluents into these water bodies (Malakootian et al., 2009). This study therefore undertaken to assess the level of heavy metals in paint industry effluent and to investigate the effects of these effluent on the growth performances and biomass production of Telfairia occidentalis.

\section{MATERIAL AND METHODS \\ Experiment location and sources of Experimental Materials}

This experimental setup was carried out in the green house of Plant Science and Biotechnology Department, Faculty of Science, University of Port Harcourt, Rivers State. Fresh fruits of Telfiaria occidentalis were obtained from a farmer in Uyo Local Government Area, Akwa Ibom State. Top soil obtained from Aluu, Omukiri. The effluents were obtained from Peacock Paint Industry Ikot Ekang, Etinan Local government Area, Akwa Ibom State at the main discharged point and sedimentation tank and were refrigerated at $6^{\circ} \mathrm{C}$

\section{Pollution of soil samples}

Six kilograms $(6 \mathrm{~kg})$ of loamy soil was weighed into perforated bags of $40 \mathrm{~cm} \times 40 \mathrm{~cm}$. Each soil thoroughly mixed with $30,50,70,90 \mathrm{mls}$ of paint effluent and incubates for three days (Udo and Oputa, 1984). The unpolluted soil served as control for each treatment (Amadi et al., 1992; Esenowo and Umoh, 1996). The soil sample was mixed with hand trowel to achieve uniformity for three days after which placing into the pails and bags and four of each seeds was placed into the polybags

\section{Analysis of soil samples}

The soil samples were analyzed for physicochemical properties; $\mathrm{pH}$, organic matter, total nitrogen, available phosphorus, exchange calcium, exchange nitrogen, exchange potassium, exchange acidity, electrical conductivity, bases saturation, silt, clay, exchange magnesium, organic carbon, carbon/nitrogen ratio, and particle sizes sand (A.O.A.C, 1995).

\section{Analysis of paint effluent}

The paint effluent was subjected for analysis to know its properties; $\mathrm{pH}$, total dissolve solids, total suspended solids, conductivity, biochemical oxygen demand, total kjeldahl, Phosphate, Chlorine, Sulphate, Iron, lead, Arsenic, Magnesium, Nickel, Copper, and Zinc.( A.O.A.C, 1995).

\section{Pre- germination studies}

Four seeds of fluted pumpkin were planted directly into the bags that contain the amended polluted soil under day light condition and the plants watered as need arose. This experiment was allowed to grow for twelve weeks to determine the growth performance. However, the growth parameters were taken after first four weeks of planting. (Esenowo and Umoh, 1996).

\section{Determination of growth performance}

The growth parameters such as plant height, leaf length, leaf width, inter-node, and petiole length was measured with meter rule in centimeters at first four weeks of planting further readings were taken. After harvesting, the root length was measured, fresh and dry weight as well as chlorophyll content was determined.

\section{Statistical analysis}

The growth parameters were subjected to oneway analysis of variance (ANOVA) to determine the level of significance using standard method of (Sokal and Rohlf, 1995).

\section{RESULTS AND DISCUSSION}

The experimental soil (the sandy-loamy top soil) was rich in bases saturation, carbon/nitrogen ratio, particle sizes, sand and available phosphorus while exchange magnesium, organic carbons, organic matter and total nitrogen were relatively low in their values (Table I.). The chemical constituents and heavy metal components of the paint effluents were analysed. The $\mathrm{pH}$, Iron, Lead, Magnesium, Nickel, Copper and Zinc content of the paint effluent was found to be $6.99,20,1,5,0.1,14.3$ and $35.6 \mathrm{mgL}^{-1}$ respectively. These values were found to be far above the FEPA's statutory limit. However, Arsenic was not detected in the paint effluent (Table 2). It is noted that there was a marked reduction in the parameters and chlorophyll content at $30 \%$ to $90 \%$ with increased concentration of the paint effluent as compared to the control (Figures 1-3). 
BAJOPAS Volume 12 Number 1, June, 2019

This is in line with the study of Nawaz and Yasmin (2006) who reported that industrial effluent has an effect on the germination of seedlings. . This could be due to the effects of toxic metals present in the effluent. This claim is also in line with the work of Akaniwor et al., (2005) who reported that soil polluted with paint effluent are phyto-toxic to growth of plants with high content of heavy metals which deteriorates the amount of physiochemical properties of the soil. Ramasubramaniam et al. (1993) in a similar study on Phaseolus mungo found out that a decrease in plant fresh and dry weight parallel a decrease in leaf pigment (chlorophyll $a$ and $b$ ). This explains in this study, the change in colour of leaves from green to yellow and the consequent reduction in chlorophyll as the concentration of effluents increases thus affecting photosynthesis (sugar formation). There was significant difference $(p<0.05)$ between the growth parameters of the plant when exposed to various concentrations of the effluent as compared to the control.

Table 1. Physicochemical Properties of Experimental soil (Garden soil)

\begin{tabular}{cll}
\hline Parameters & Unpolluted soil & Polluted soil \\
\hline pH & 6.44 & 6.32 \\
Organic Matter (\%) & 1.76 & 4.32 \\
Total Nitrogen (\%) & 0.058 & 0.241 \\
Available P. (mg/kg) & 37.85 & 65.75 \\
Ex. Ca. (cmol./kg) & 3.66 & 5.89 \\
Ex. N. (cmol./kg) & 0.058 & 0.08 \\
Ex. K. (cmol. $\mathrm{kg})$ & 0.092 & 0.25 \\
Exchange Acidity & 2.49 & 2.45 \\
ECEC. (cmol./kg) & 7.68 & 10.63 \\
Bases Saturation (\%) & 66.78 & 77.06 \\
Silt (\%) & 4.22 & 5.88 \\
Clay (\%) & 4.40 & 8.15 \\
Exchange Mg (cmol.kg) & 1.28 & 1.91 \\
Organic Carbons & 1.66 & 3.18 \\
C/N ratio & 91.77 & 12.85 \\
Particle sizes sand (\%) & 91.80 & 86.01 \\
Ec. (Gs/m) & 0.069 & 0.0607 \\
\hline
\end{tabular}

\begin{tabular}{ll} 
Table 2: The physicochemical Properties of paint effluent \\
\hline Parameters & Paint \\
\hline Colour & White \\
pH & 6.99 \\
TSS $\left(\mathrm{mg} \mathrm{L}^{-1}\right)$ & 30 \\
Conductivity $(\mathrm{ms} / \mathrm{cm})$ & 2.1 \\
TDS $\left(\left(\mathrm{mg} \mathrm{L}^{-1}\right)\right)$ & 195 \\
COD $\left(\mathrm{mg} \mathrm{L}^{-1}\right)$ & 110 \\
BOD & $\left(\mathrm{mg} \mathrm{L}^{-1}\right)$ \\
TKN $\left(\mathrm{mg} \mathrm{L}^{-1}\right)$ & 35 \\
Phosphate $\left(\mathrm{mg} \mathrm{L}^{-1}\right)$ & 60 \\
Chlorine $\left(\mathrm{mg} \mathrm{L}^{-1}\right)$ & 5 \\
Sulphate $\left(\mathrm{mg} \mathrm{L}^{-1}\right)$ & 700 \\
Iron & 550 \\
Lead & 20 \\
Arsenic & 1 \\
Magnesium & $\mathrm{ND}$ \\
Nickel & 5 \\
Copper & 0.1 \\
Zinc $\left(\mathrm{mg} \mathrm{L}^{-1}\right)$ & 14.3 \\
\hline
\end{tabular}




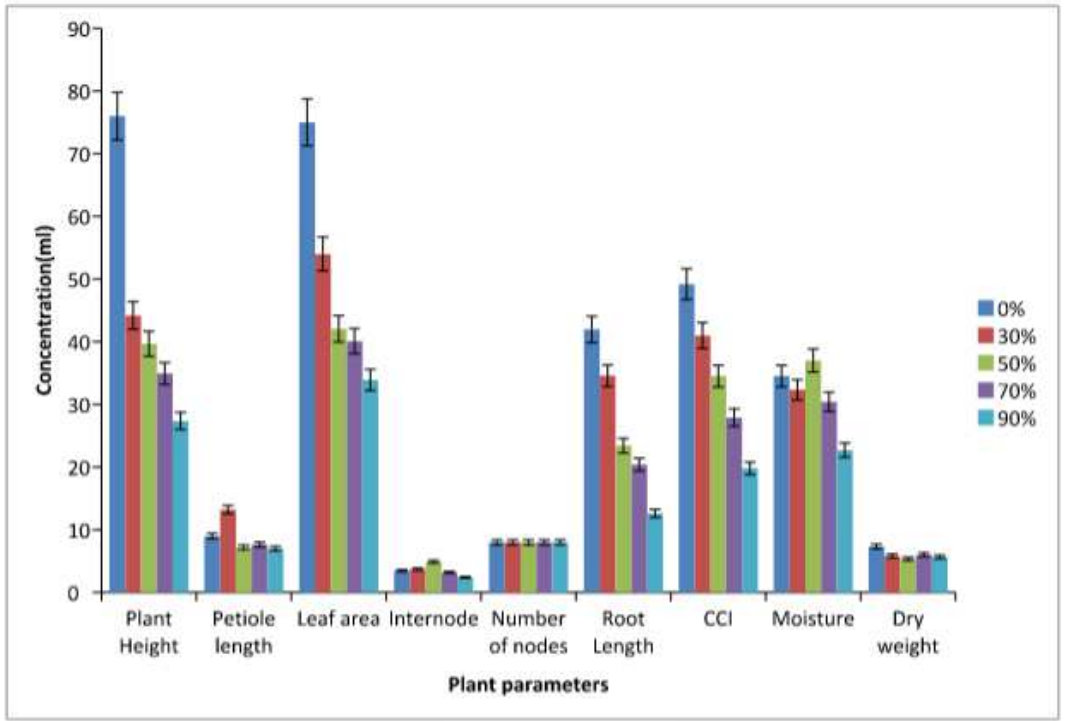

Figure 1: Effect of paint effluent on the growth performance and biomass production of Telfairia occidentalis at four weeks.

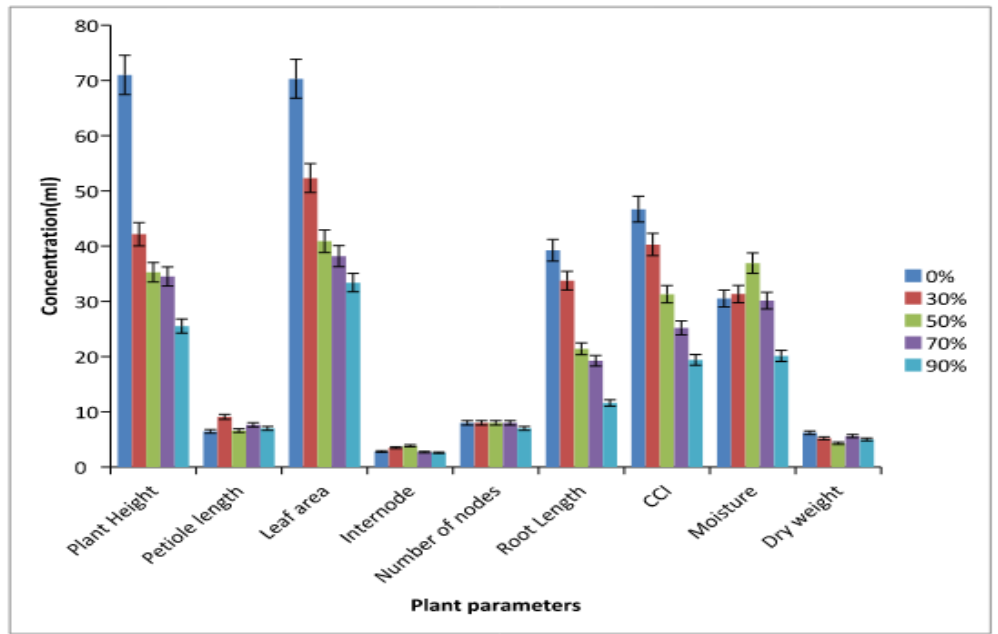

Figure 2: Effect of paint effluent on the growth performances and biomass production of Telfairia occidentalis at Eight weeks.

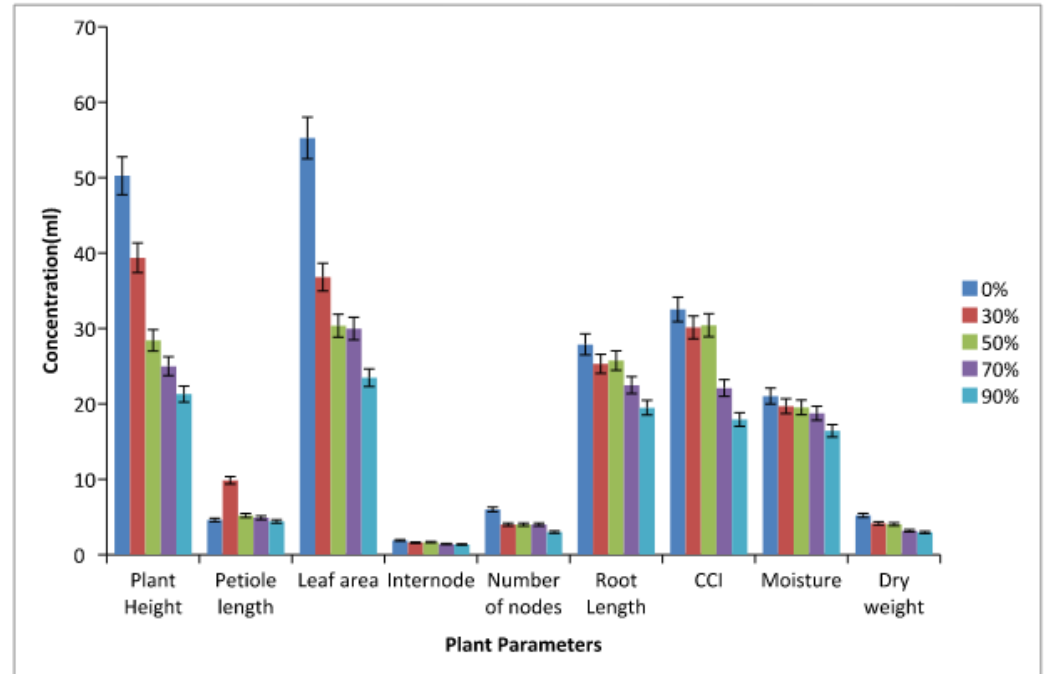

Figure 3: Effect of paint effluent on the growth performance and biomass production of Telfairia occidentalis at Twelve weeks. 


\section{CONCLUSION}

This study has shown that paint effluents contained some harmful pollutants such as heavy metals which are dangerous to life such

\section{REFERENCES}

A.O.A.C. (1995). Association of Official Analytical Chemist. Method of Analysis, $10^{\text {th }}$ and $17^{\text {th }}$ ed. USA: Washington DC press, pp.201-205

Akaniwor, J.O., Onyeike, E.N. and Ifemeje, L. (2005). Effect of trace element of crude oil contaminated soil. Environ. Sci. Technol. 56:720-725

Alada, A.R.A (2000). The haematological effects of Telfiaria occidentalis diet prepation. African Journal Biomed Research, 3(3): 185-186.

Amadi, A., Dickson, A.A. and Maaire, G. O. (1992) Remediation of oil polluted 66: $59-76$ soil, air and water. J. soil Sci.,

Dönmez, G.; Aksu, Z.; Özturk A.; Kutsal, T., (1999). A comparative study on heavy metal biosorption characteristic of some algae. Process. Biochem., 34 (9), 885-892.

Esenowo, G. J. and Umoh, N. S. (1996). Effect of used engine oil pollution on growth and yield of Arachis hypogea and Zea mays. Trans. Nig. Soc. Bio. Conser. 5: 700-711

Gill, L. S. (1992). Ethnomedical uses of plants in Nigeria. Benin: uniben press, pp. 228-229

Igbinosa, E. O.; Okoh, A. I., (2009). Impact of discharge wastewater effluents on the physico-chemical qualities of a receiving as plants. It is suggested that further study on the genotoxicity of Industrial effluents on the same plant Telfairia occidentalis Hook (F.) be embarked upon.

watershed in a typical rural community. Int. J.Environ. Sci. Tech., 6 (2), 175-182

Malakootian, M.; Nouri, J.; Hossaini, H., (2009). Removal of heavy metals from paint industries wastewater using Leca as an available adsorbent. Int. J. Environ. Sci. Tech., 6 (2), 183-190.

Nawaz, S., S.M. Ali and A. Yasmin, (2006). Effect of industrial effluents on germination and early growth of Cicer arientum. $J$. Biol. Sci., 6: 49-54.

Ramasubramaniam, V., V. Rarichandran and Kanan, (1993). Analysis of industrial effluents and their impact on the growth and metabolism of Phaseolous mango L. Commun. Soil Sci. Plant Anal., 11: 22412249.

Renner, S.S., Scaefer, H. and koccyam, A. (2007). Phytogenetics of cucumis (curbitaecae). The production of telfiaria occidentalis in Nigeria in the hand of few ethnofarmers. Journal of Animal and plant science, 5(1): 443-449.

Sokal, R.R and Fohlf, F. J. (1995) Biometry. New York: Colt Freeman and Company, p. 887

Udoh, D. J., Ndon B.A., Asuquo, P.E. and Ndaeyo, N.U (2005). Crop production technique for the tropic. Nigeria: published limited, pp. 210-240

Weiner M. A. (1992) Earth medicine. New York: Macmillan, p. 12 